\title{
LOST RELICS: PROBLEM OF PRESERVATION OF MONUMENTS OF ARCHITECTURE AND HISTORICAL LOOK OF KURSK
}

\author{
Anna Alekseevna Dorodnykh* \\ Southwest State University, Kursk, Russia
}

The article will consider the important problem of preservation and usage of historical and cultural heritage, observe the researches on the history of architecture, contemplate objects of landscape gardening architecture, conditions for their advent and development in the historical center of Kursk. Description of valuable architecture objects under the conditions of urban environment is provided. The research is pointed at modernization of the approach for reconstruction of the most valuable monuments of architecture in Kursk and serves as the base for practical activity - reconstruction of historical and architecture heritage objects in historical center of the city.

Key words: Architecture relic, Historical look of the city, Historical and architecture heritage, Restoration, Reconstruction

\section{INTRODUCTION}

The concept "monument of architecture» is characterized not only by the objects of the cultural heritage under the protection of the state. This category also includes buildings of common building system of the Soviet and pre-revolution period. Demolition of such buildings is a grievous loss for a historical look of any city. The issue of reconstruction of lost monuments of architecture is the increasingly discussed theme among metropolitan city planners and businessmen, however, in Kursk this issue is out of attention, in fact, the tendency for destruction of such monuments is observed. In general the current situation in the area of protection of the cultural heritage in Kursk is unfortunate. The main reason is lack of resources both material and human, what does not allow to get across the significance of architecture monuments and non-renewability of their loss the to the government and citizens.

The bases for variety of urban environment are objects, constructed in different epochs. Preservation of separate buildings and whole construction complexes - representatives of different art styles and historical epochs is the important part in forming the look of a modern city.

The important task of the state cultural policy is the strategy of preservation and reconstruction of the objects of cultural heritage what is the ba- sis of the development of the all-Russian cultural identity.

Preservation of heritage - one of the most necessary conditions of the firm development of the country, provision of its national security, integrity and variety of its cultural space. Cultural heritage, monuments of history, nature and culture testify and reflect the greatness of history and versatility of traditions of the country, Russia. That is why the preservation of the cultural heritage shall have the priority meaning for the policy of the country and regions.

\section{RETROSPECTIVE ANALYSIS OF FORMING OF THE HISTORICAL LOOK OF KURSK}

Today the theme of cultural memory is especially pressing, but without turning to the sources it is impossible to provide the full insight into it. Large trade cities in the central regions of Russia have a rich history. Kursk has the unique natural relief on which an inimitable architecture ensemble has formed. The first annalistic note about Kursk dated back to 1032. As many ancient Russian cities Kursk appeared on place of a Slavic settlement transformed into a fortress for protection of Kursk lands from nomad raids. Archeological researches show, that at the place of modern Znamensky monastery of Kursk there was a large community and in the Middle Ages there was the capital of Kursk principality. Later the 
a part of the Great Lithuanian principality, and then it came under the Moscow state's government. The pre-revolutionary Kursk was relatively small provincial center, but with a pretty developed industry. It didn't distinguish itself by some special architectural and historical riches, but was very picturesque. Znamensky monastery was its heart, located at the edge of a sheer drop on a high shore of Tuskar river [01, 02].

In the period of war of 1941-1945 the name of Kursk became associated with one of the greatest battles in the history. Though the city was massively damaged during the liberation, it managed to save many objects of cultural heritage. Some objects were erased from the map of the city during the October Revolution, some - during the World War II and some came down due to decay as superfluous. For the past century Kursk has grown and changed a lot, striving to preserve its inimitable, recognizable look.

\section{MORPHOTYPE OF THE BUILDING SYSTEM OF KURSK}

The bright example of the historical building system peculiar for the city is Dzerzhinskogo (ear- lier known as Khersonskaya) street. This is the second main street of Kursk, which got its name in 1782 in accordance to the first city planning in honor of a new at that moment port Kherson in the Black Sea. The widest at that moment Khersonskaya street was quickly lined up by wooden and stone houses many of which served as trading establishments and many beautiful stone houses for nobility and traders.

Today this part of the city looks especially sorrowful. A spectacular example of distinguishing of the historical heritage is Georgievskaya pharmacy liquidation (Figure 1) of the end of XVIII - beginning of XIX centuries, which most recently was located on the corner of Dzerzhinskaya street and Gaidara street. This pharmacy in due time got its name after the orthodox temple, located at the neighboring street which lead to another temple - Blagoveschensky. Both were destroyed in the past century's 30 s and from Georgievsky temple was left only the name of the pharmacy. The building was demolished on August 10, 2013, nevertheless its status of "reopened object of cultural heritage".

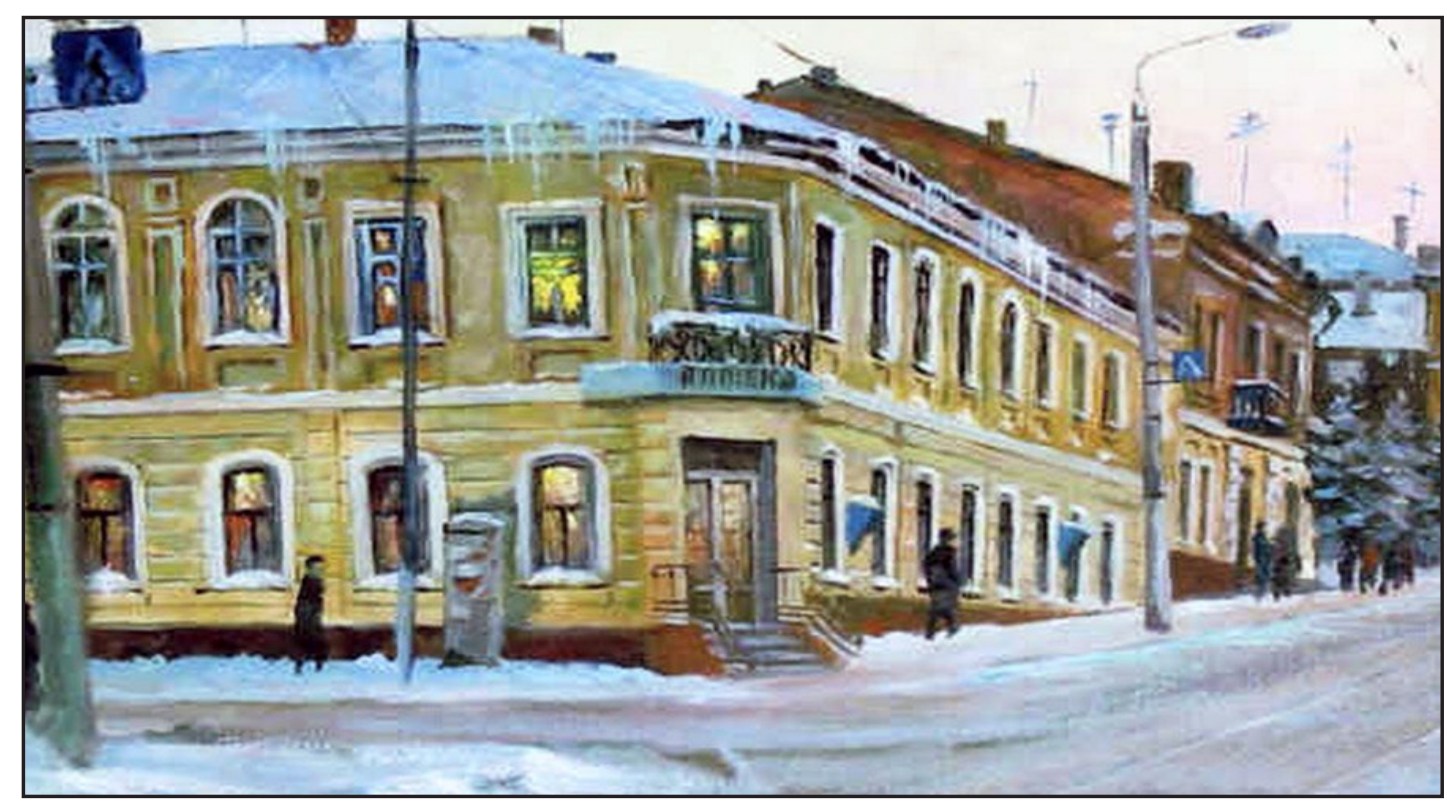

Figure 1: The building of the Georgievskaya pharmacy, artist - Tsymbulov V.I.

The similar situation is on the other side of the street - there has been preserved just few historic mansions, which maintained untouched mainly thanks to their present owners' efforts.

The next historical building awaits a decision from the municipal administration of Kursk - trader Tolubeev's house on Dzrzhinskaya street (Fig- ure 2.), which was recently recognized as dangerous. The building is included in the list of objects of cultural heritage of regional significance of Kursk region as a monument of architecture. The mansion was constructed in the end of XIX century with use of Middle Age architecture elements, such as turrets and unusual architecture 


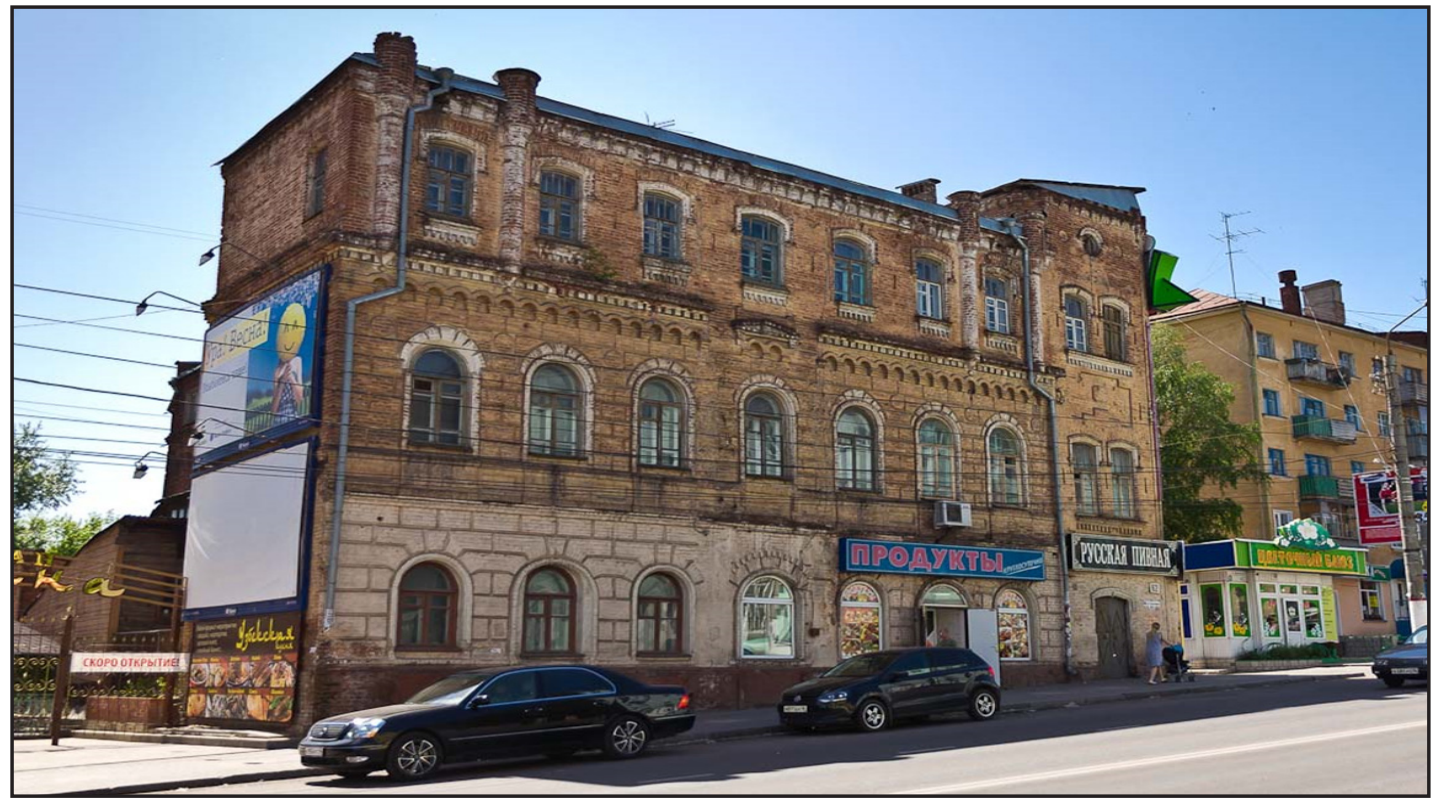

Figure 2: Trader Tolubeev's house

devices and number of stories in the building. Today the nobles' house is a bright example of the historical Kursk of which fewer and fewer left each year. If the city will lose such an architectural highlight the look of the regional center suffers irreparable damage.

The more monuments of different periods of construction the city has the more it is interesting; the more it attracts the attention. But in the larger scheme of things, we need not only to save buildings from extinguishing from the map of the city, but to do reconstruction and restoration works for the most valuable of the lost objects. Only the very few objects can be identified as monuments having historical and architectural value. But these rare objects are so valuable that can testify about the true culture of city planners of the city.

According to the words of the deputy governor of the Kursk region S. Dyumin, there are several projects on reconstruction of the historical center. For example there shall be "Center of historical and cultural heritage of the city of Kursk" with Sobornaya square, museum, art gallery, park zones and fountains in the area of Znamensky cathedral.

But still as been noted the negative tendency is observed which directed not on preservation but on the struggle with cultural values. The bright example - demolition of the old "Trader Naumov's house" built in the end of XIX - beginning of $X X$ centuries. According to the order № 01 09/52 from February 21, 2012 this building along with 17 other valuable buildings was deprived of the special status and pulled out of the list of reopened objects of historical, scientific, artistic or other cultural merit. On March 28, 2017 the building was ruthlessly demolished. The same fate threatens other objects and the city can lose its history and uniqueness. There are few buildings preserved in Kursk, the look of which can give us a chance to understand how the city looked like in 19th or 20th centuries. From now on "Trader Tolubeev's house" exists only in photographical history of the city (Figure 3.)

\section{THE CITY GARDEN AS THE OBJECT OF HISTORICAL, CULTURAL, ARCHITECTURAL AND CITY BUILDING HERITAGE}

Not only monuments as the type of objects of cultural heritage shall be under the protection: works of landscape architecture and gardening architecture, namely, parks, gardens and squares shall also be under the protection of the state. In 1817 the emperor Alexander I confirmed the rules for organizing cities, settlements and roads. The said rules prescribed local authorities to organize a community garden in each provincial city. However the peak of building and providing of amenities was later - at cusp of XIX and $X X$ centuries. In this period a lot of new, spacious buildings constructed for many educational and other public institutions, a lot of banks, trade and commercial apartment buildings together with squares and parks $[03,04]$. 


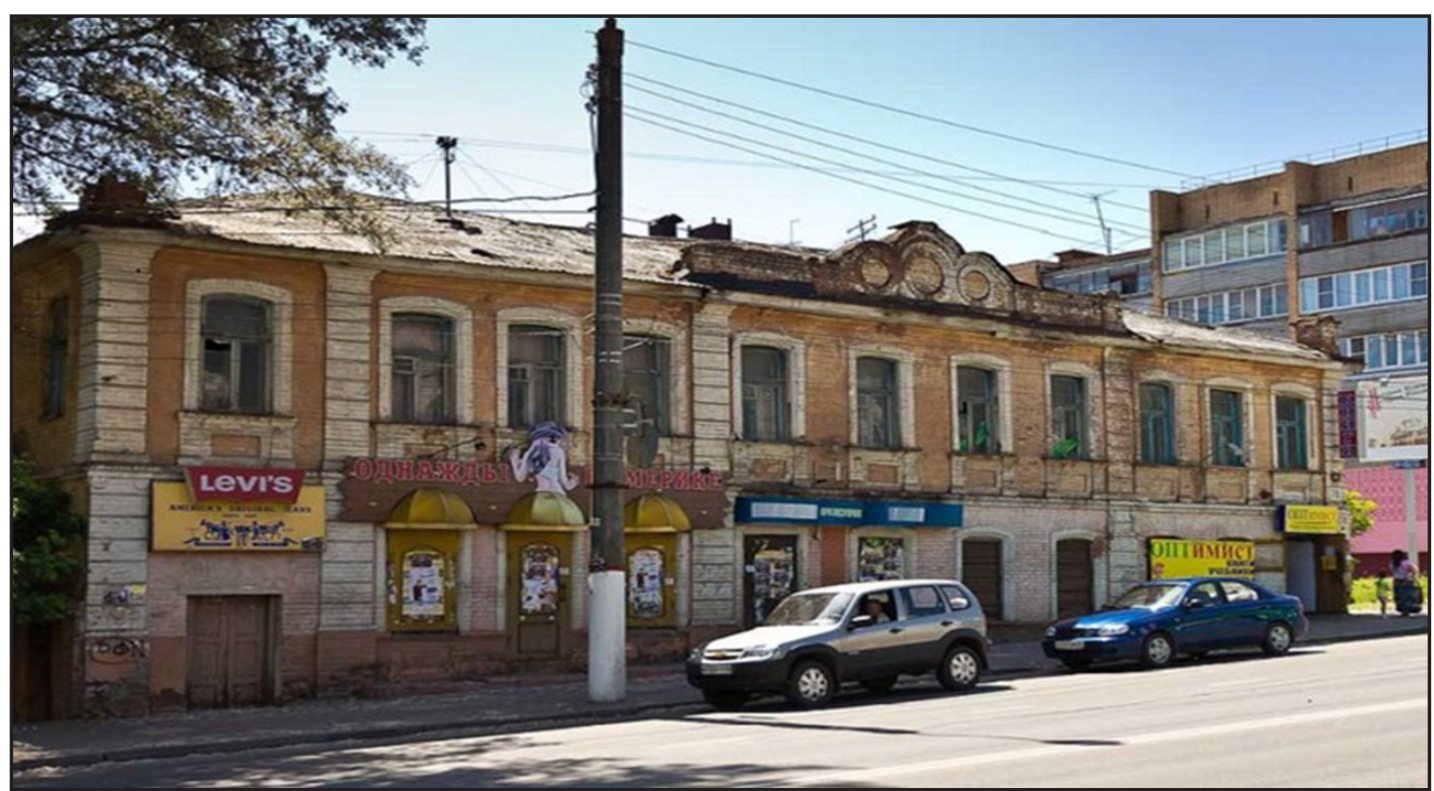

Figure 3: Trader Naumov's house

The guide for Kursk from 1902 [05] describes in details the central part of the city and architecture of its historical part. According to the guide in 1869 on the Red Square there was a municipal garden with alleys and roads set up for walking. The center of architectural composition of the garden was the building of a fit-up, which gave performances and where people's readings were organized. On Figure 4 you can see the building of the fit-up in the public garden, and in the center - bust of A.S. Pushkin, set to celebrate the centenary of the poet's birth.

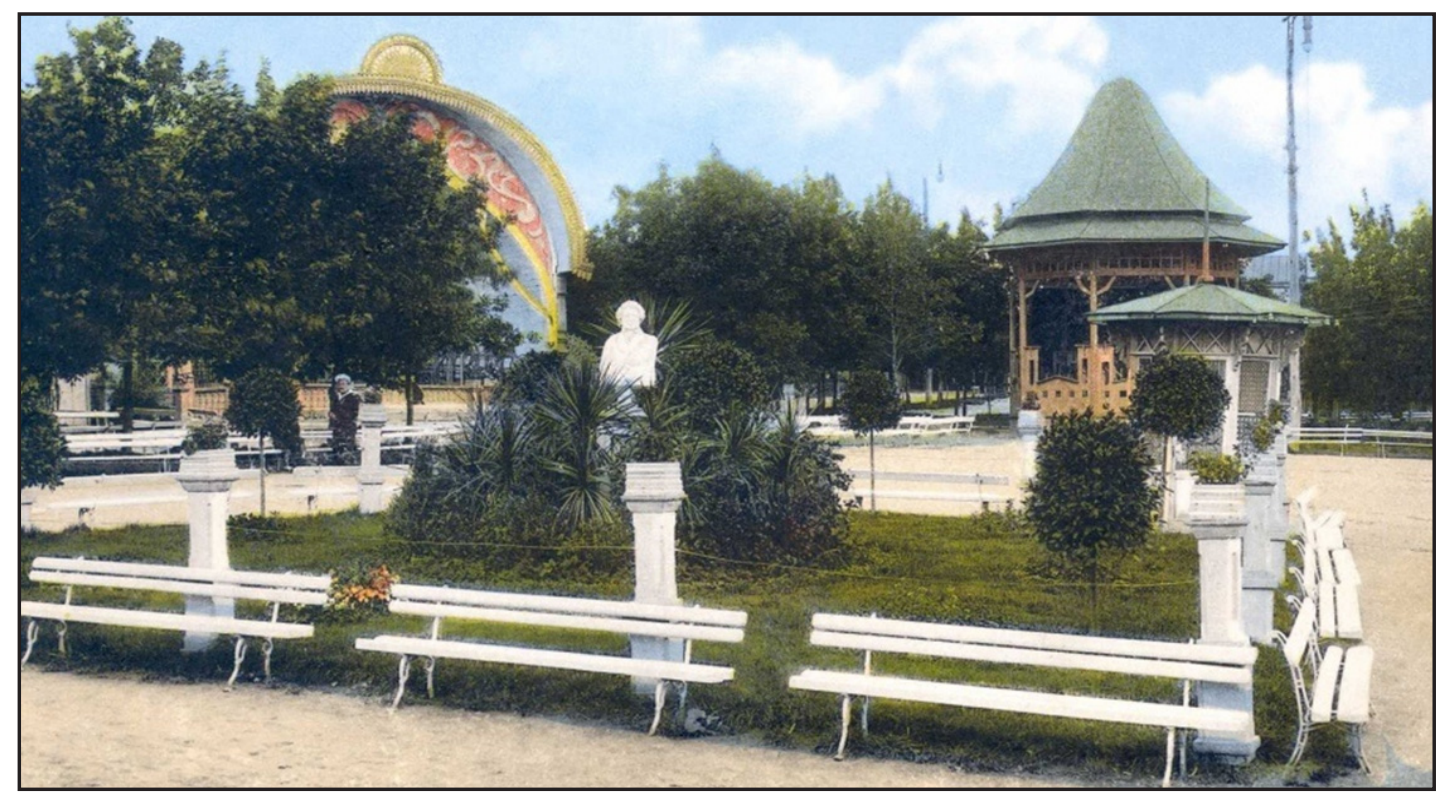

Figure 4: Public garden

Hard landscaping such as fountains, gazebos and opened scenes helped to diversify the garden and created historical and art value, they were the gravity center for people living in Kursk in this time. The south side of the public garden adjoined the square, made of two wide roads. Having gone up from the square on the oppo- site hill, we can find the Avraamovskaya street, now it is Khalturina street and then to the Sadovaya street, where in 1799 appeared the garden which is now lost. Being located on the other side from the hospital it got the name of Lazaretny (translator's note Lazaret «лазарет» - Russian for "hospital"). The entrance to the Lazaretny 
garden was made as a large brick half-rotunda. This beautiful construction was built in 1827 . The magnificent colonnade was visible perfectly from different parts of town, but by 30 s it was close to destruction and soon constructors dismantled it. The width of the garden wasn't big, just a little less than two hundred meters. The garden occupied the whole block and was made of wildlife trees. Down the ages this garden was the favorite place for promenade and entertainment of natives of Kursk. The central parkway of the garden looked down on the square, from which a beautiful look opened on the adjacencies and river valley of river Kur and Kazatskaya quarter, what made the garden uncommonly picturesque and attractive for citizens. In former times there were set fireworks and dances, labyrinth, grottoes and gazeboes were built for visitors. The main square of the garden were garnished with planters and fountains.

In the beginning of the World War I the surgical suit served as a hospital and by the beginning of the Great Patriotic War there was no Lazaretny garden at bottom - the war erased it from the map of the city. The surgical suit, built on the territory of the garden, held military hospitals and during the occupation the German military base was located here. Now by looking on the facades of two hospital buildings it is hard to imagine this place as it was in the old times - cozy, noisy and festive [06].

Having studied the history of the garden and its uneasy history we can ask a question: is it possible to reconstruct this lost monument of landscape architecture as it was? Reconstructed Lazaretny garden may become the source of enrichment with new spectacular views on dynamically changing city. Restoration and reconstruction of public gardens and parks is a separate and very pressing topic, which remains almost without attention and undeservingly forgotten. Meanwhile reconstruction of objects of landscape architecture is a difficult and highly claimed type of restoration works. In the context of necessity of reconstruction of integrity of the picture of the city in the pre-revolutionary times we need to revive traditions of making landscape architecture projects. Reconstruction of jewels of the landscape planning need to be carried out with the help of the historical materials and archive photographs, scrupulously create the picture of a garden of a park in the period of its bloom. The main factor in reconstruction of space layout structure of the given objects is rigorous follow to the historical elements - planning and forms of small statuary (benches, urns, lanterns, lawn enclosures, fences). Exactly those little on the first view details make the object of reconstruction truly magnificent.

\section{CONCLUSIONS}

The architecture look of any city is influenced by many factors: architecture ensembles of the historical part of the city, modern public and accommodation buildings and also the state of the objects of landscape architecture. To preserve and improve the historically formed look of the city we need to develop the strategy of reconstruction of historically valuable objects, both lost and those which haven't lost their special status. The considered examples of architectural and space forming of the historical center of the city and determining the tendencies for destruction of monuments of culture, history and architecture testify the necessity of use of new concepts of development of the succession principle based on research of the history of the city, traditions of forming of public gardens, squares and parks. At the moment it is important to realize the value of rebirth of spiritual traditions and creative ideas, which can be seen through study of the history of the city. There is a necessity to search ways for further preservation, restoration and reconstruction of valuable architecture objects under the conditions of urban environment. These examples shall clearly demonstrate the sorrowful state of cultural monuments, note on the loss of the historical look of the central part of the city. 


\section{REFERENCES}

1) Dorodnykh A.A., Strel'tsova A.A., Grankin I.N. (2016): Arkhitekturnye ocherki goroda Kurska, Aprobatsiia. 2016. № 2 (41). pp. 19-21.

2) Dorodnykh A.A., ApukhtinaA.S. (2016): Problema restavratsii i rekonstruktsii istoricheskikh zdanii g. Kurska i Kurskoi oblasti, Molodoi uchenyi, 2016. № 6 (110). pp. 91-94.

3) Kalendar' i pamiatnaia knizhka Kurskoi gubernii na 1884 g. (1883), Kursk, 242 p.

4) Opisanie Kurskogo namestnichestva ot drevnikh i novykh raznykh o nem izvestii sobrannoe Sergeem Larionovym togo namest- nichestva verkhnei raspravy prokurorom (1786), Moskva,197 p.

5) Zlatoverkhovnikov N.I. Kurskii sbornik, s putevoditelem po gorodu Kursku i planom gorod (1912), Kursk, $125 \mathrm{p}$.

6) Stepanov, V. Ploshchad' Perekal'skogo. Putevoditel' po istoricheskomu tsentru goroda Kurska (2008), Kursk, 184 s.

Paper sent to revision: 26.07.2017.

Paper ready for publication: 04.09.2017. 